\title{
DERIVATION OF URANIUM RESIDUAL RADIOACTIVE MATERIAL GUIDELINES FOR THE SHPACK SITE
}

by

J.-J. Cheng, C. Yu, F. Monette, and L. Jones

Environmental Assessment and Information Sciences Division

August 1991

work sponsored by

U.S. Department of Energy

DOE Field Office

Former Sites Restoration Division

Oak Ridge, Tennessee 


\title{
DERIVATION OF URANIUM RESIDUAL RADIOACTIVE MATERIAL GUIDELINES FOR THE SHPACK SITE
}

\author{
by
}

J.-J. Cheng, C. Yu, F. Monette, and L. Jones

Environmental Assessment and Information Sciences Division

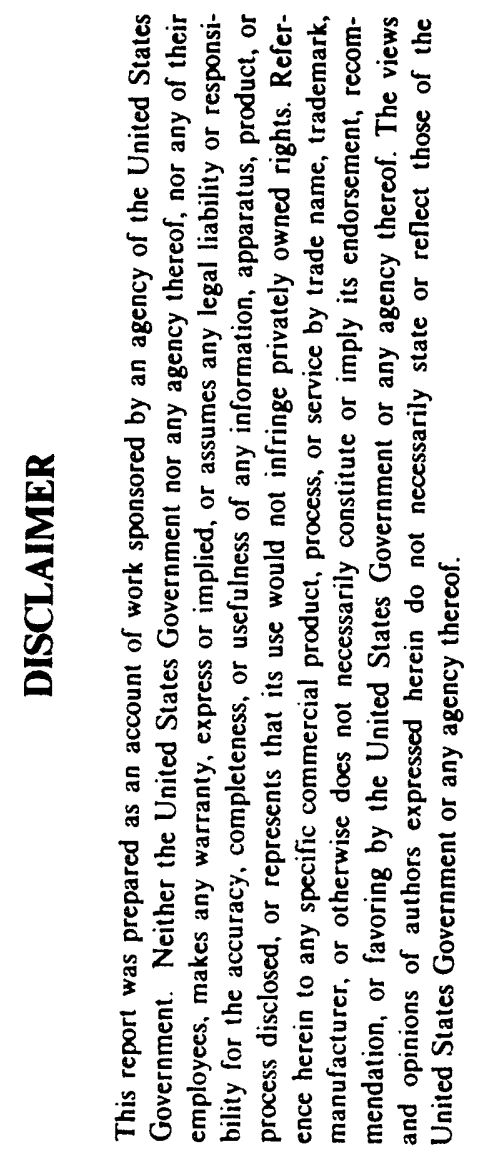

August 1991

\author{
work sponsored by \\ U.S. Department of Energy \\ DOE Field Office \\ Former Sites Restoration Division \\ Oak Ridge, Tennessee
}




\section{CONTENTS}

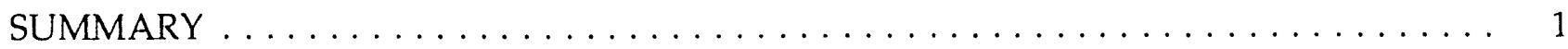

1 INTRODUCTION AND BRIEF HISTORY $\ldots \ldots \ldots \ldots \ldots \ldots \ldots \ldots \ldots \ldots \ldots \ldots$

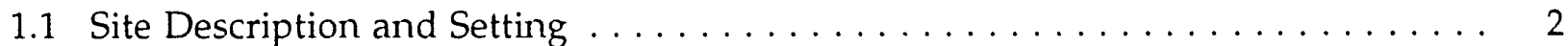

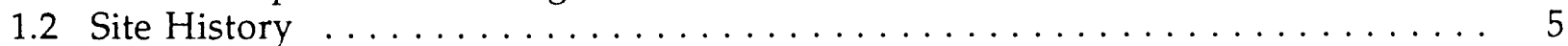

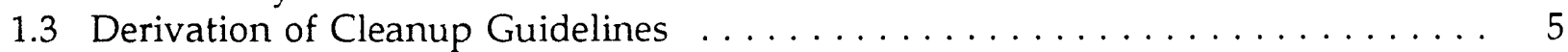

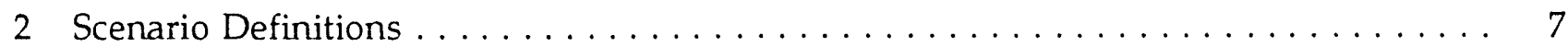

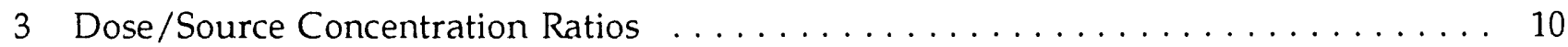

4 Residual Radioactive Material Guidelines . . . . . . . . . . . . . . . . 14

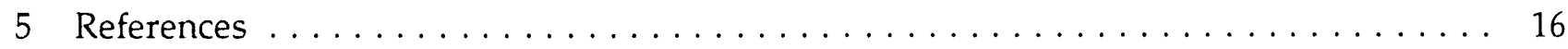

APPENDIX: Parameters Used in the Analysis of the Shpack Site $\ldots \ldots \ldots \ldots \ldots$

\section{FIGURES}

1 Location of the Shpack Landfill Site $\ldots \ldots \ldots \ldots \ldots \ldots \ldots \ldots \ldots \ldots$

2 Site Map of the Shpack Landfill Site $\ldots \ldots \ldots \ldots \ldots \ldots \ldots \ldots \ldots$

\section{TABLES}

1 Summary of Pathways for Scenarios A, B, and C at the Shpack Site ........ 9

2 Maximum Dose/Source Concentration Ratios for Scenario A at the Shpack Site ............................... 11

3 Maximum Dose/Source Concentration Ratios for Scenario B at the Shpack Site .............................. 11

4 Maximum Dose/Source Concentration Ratios for Scenario $C$ at the

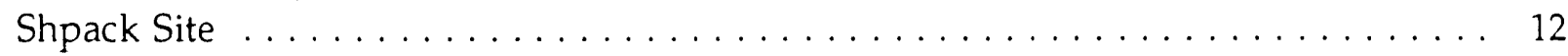

5 Total Dose/Source Concentration Ratios for Uranium at the Shpack Site . . . . . . 12

6 Example Total Dose/Source Concentration Ratios for Total Uranium at the Shpack Site . . . . . . . . . . . . . . . . . . . . . 13

7 Residual Radioactive Material Guidelines for the Shpack Site . . . . . . . . . . . 14 


\section{TABLES (Cont'd)}

8 Example Total Uranium Residual Radioactive Material Guidelines

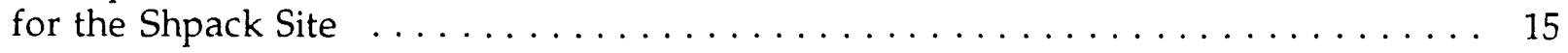

A.1 Parameters Used in the RESRAD Code for the Analysis of the Shpack Site . . . . . 17 


\title{
DERIVATION OF URANIUM RESIDUAL RADIOACTIVE MATERIAL GUIDELINES FOR THE SHPACK SITE
}

\author{
by
}

\author{
J.-J. Cheng, C. Yu, F. Monette, and L. Jones
}

\begin{abstract}
SUMMARY
Residual radioactive material guidelines for uranium were derived for the Shpack site in Norton, Massachusetts. This site has been identified for remedial action under the Formerly Utilized Sites Remedial Action Program (FUSRAP) of the U.S. Department of Energy (DOE). The uranium guidelines were derived on the basis of the requirement that the 50-year committed effective dose equivalent to a hypothetical individual who lives or works in the immediate vicinity of the Shpack site should not exceed a dose of $100 \mathrm{mrem} / \mathrm{yr}$ following decontamination. The DOE residual radioactive material guideline computer code, RESRAD, which implements the methodology described in the DOE manual for implementing residual radioactive material guidelines, was used in this evaluation. Three potential scenarios were considered for the site; the scenarios vary with regard to time spent at the site, sources of water used, and sources of food consumed. The results of the evaluation indicate that the basic dose limit of $100 \mathrm{mrem} / \mathrm{yr}$ will not be exceeded for uranium (including uranium-234, uranium-235, and uranium-238) within 1000 years, provided that the soil concentration of combined uranium (uranium-234 and uranium-238) at the Shpack site does not exceed the following levels: $2500 \mathrm{pCi} / \mathrm{g}$ for Scenario A (recreationist: the expected scenario); $1100 \mathrm{pCi} / \mathrm{g}$ for Scenario B (industrial worker: a plausible scenario); and $53 \mathrm{pCi} / \mathrm{g}$ for Scenario $C$ (resident farmer using well water as the only water source: a possible but unlikely scenario). The uranium guidelines derived in this report apply to the combined activity concentration of uranium-234 and uranium-238 and were calculated on the basis of a dose of $100 \mathrm{mrem} / \mathrm{yr}$. In setting the actual uranium guidelines for the Shpack site, DOE will apply the as low as reasonably achievable (ALARA) policy to the decision-making process, along with other factors, such as whether a particular scenario is reasonable and appropriate.
\end{abstract}




\section{INTRODUCTION AND BRIEF HISTORY}

The Formerly Utilized Sites Remedial Action Program (FUSRAP) was established in 1974 by the U.S. Atomic Energy Commission (AEC), a predecessor of the U.S. Department of Energy (DOE). The mandate of the program is to identify, evaluate, and, if necessary, decontaminate sites previously used by the AEC or its predecessor, the Manhattan Engineer District (MED).

The Shpack site is located in Norton, Massachusetts. It was designated by DOE as a candidate for remedial action under FUSRAP, after Oak Ridge National Laboratory (ORNL) conducted a radiological survey of the site in 1980 (Bechtel National, Inc. 1984). The proposed remedial action for the site will follow the guidelines established in DOE Order 5400.5 (DOE 1990). The RESRAD computer code (Gilbert et al. 1989) is used to derive residual radionuclide guidelines on a site-specific basis. This report presents the uranium guidelines derived for the Shpack site on the basis of a dose limit of $100 \mathrm{mrem} / \mathrm{yr}$.

\subsection{SITE DESCRIPTION AND SETTING}

The Shpack landfill site is located on Union Street in the townships of Norton and Attleboro, Massachusetts, approximately $56 \mathrm{~km}$ (35 mi) southwest of Boston (Figure 1). The site covers an area of 3.2 ha ( 8 acres); 2.2 ha (5.5 acres) are located within the Town of Norton, and the remaining 1.0 ha ( 2.5 acres) is located within Attleboro corporate limits. The site is bounded on the northwest by Peckham Road, on the north by Union Road, on the south and west by the Attleboro landfill, and on the east by fields (Figure 2). The nearest residential building is located $50 \mathrm{~m}(160 \mathrm{ft})$ from the site boundary. No major commercial, industrial, or residential areas are in the vicinity.

The landfill was originally developed on swampland and continues to be poorly drained; the site is partially covered by water at various times of the year. Surface water at the site drains into Chartley Brook and Chartley Pond to the east and north, respectively. Within the landfill, the depth to the water table is generally $1.5 \mathrm{~m}(5 \mathrm{ft})$ or less; the predominant groundwater flow is north to Chartley Pond (Cottrell et al. 1981). About one-half to threequarters of the Shpack landfill is within a 100-year floodplain (Peterson 1981).

The geology of the area consists of glacial deposits overlying bedrock. The glacial overburden ranges in thickness from 4.6 to $7.6 \mathrm{~m}(15$ to $25 \mathrm{ft})$ and is overlain by organic deposits (peat) varying in thickness from 1.5 to $9.1 \mathrm{~m} \mathrm{(5} \mathrm{to} 30 \mathrm{ft}$ ) (Cottrell et al. 1981). The bedrock is folded, faulted, and metamorphosed sedimentary rock of Pennsylvanian age. Groundwater in the area is produced from both bedrock and surficial deposit aquifers.

The mean annual temperature of the area is approximately $9^{\circ} \mathrm{C}$; January is the coldest month $\left(-3^{\circ} \mathrm{C}\right)$ and July is the warmest $\left(22^{\circ} \mathrm{C}\right)$. Precipitation averages $106 \mathrm{~cm}$ (42 in.) annually, and the maximum daily rainfall is about $15 \mathrm{~cm}(6 \mathrm{in}$.). The long-term runoff for the area averages approximately $50 \%$ of precipitation. Prevailing annual winds are westerly; northwesterly winds predominate in the winter and southwesterly winds predominate in the summer. 


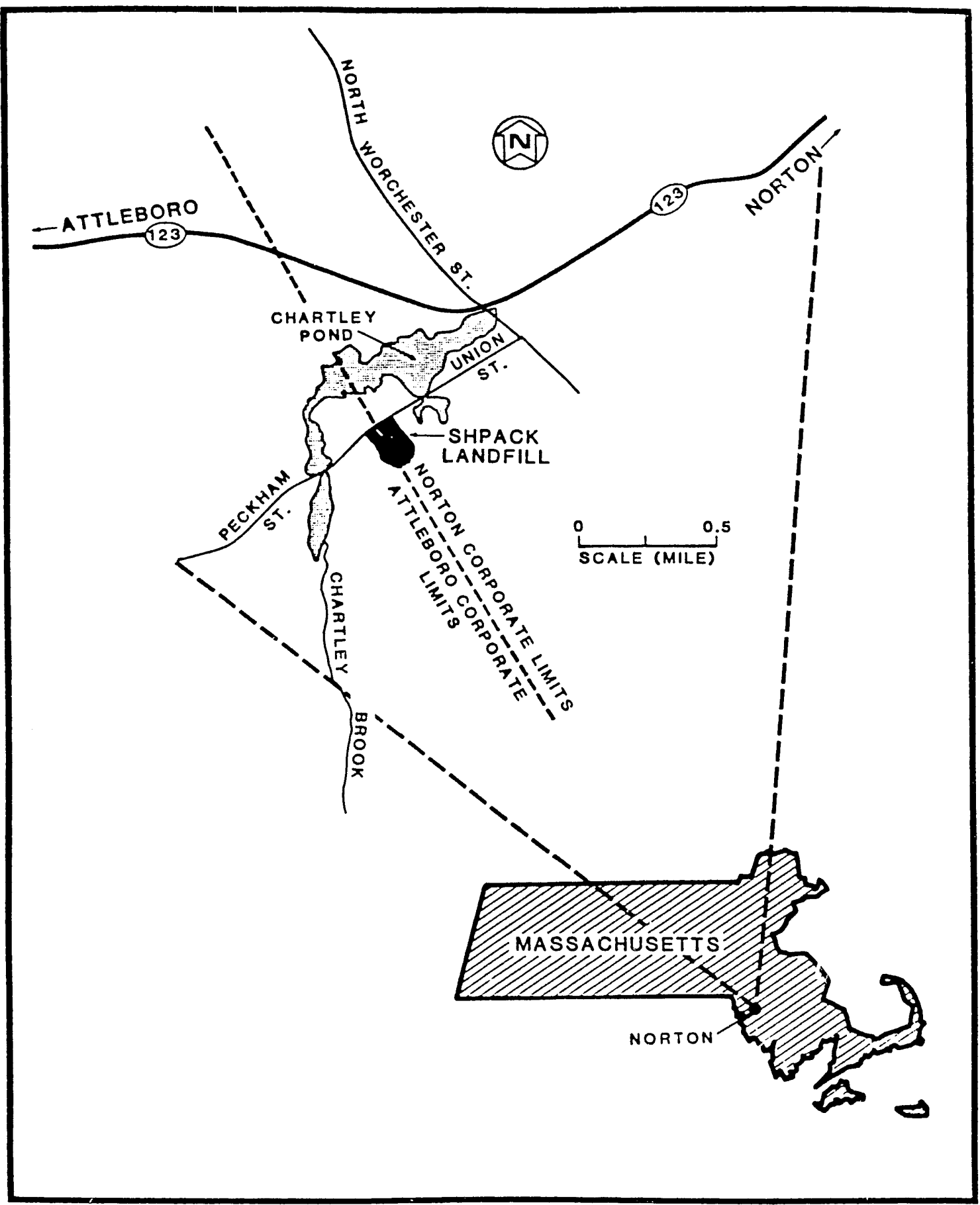

FIGURE 1 Location of the Shpack Landfill Site (Bechtel National, Inc. 1984) 


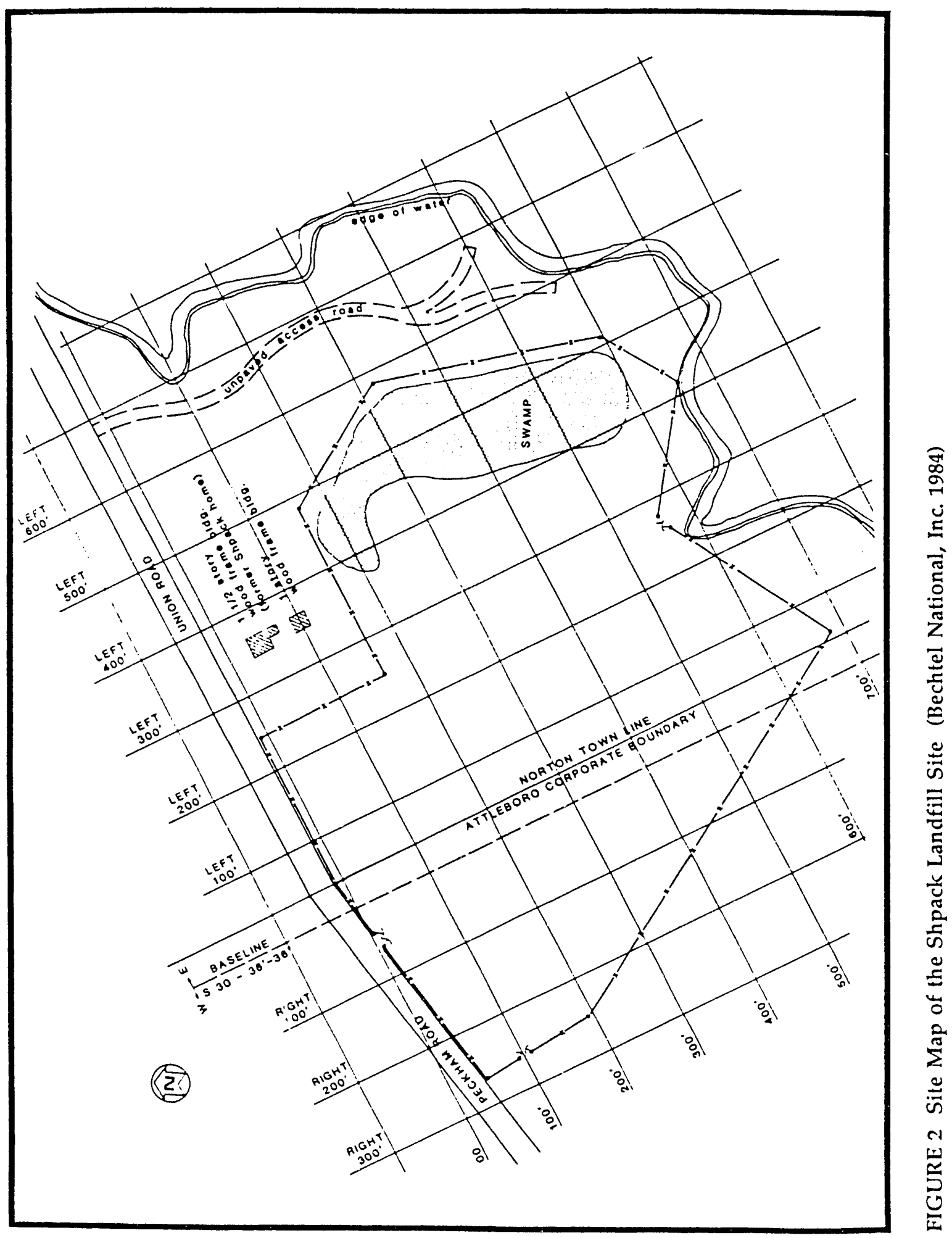




\subsection{SITE HISTORY}

The Shpack landfill was a private landfill that began operating in 1946. Major use of the landfill occurred from 1951 until 1965, when it was closed by court order. During its operational period, the landfill received both industrial and domestic wastes.

This site is reported to have received substantial quantities of potentially hazardous chemical wastes, including an unknown quantity and type of containerized material (GeoCenters, Inc. 1980). It is not known exactly when radioactive materials were deposited at the site.

In 1978, the U.S. Nuclear Regulatory Commission (NRC) conducted a special investigation of the Shpack site after being contacted by a concerned citizen who had detected elevated radiation levels at the site. The NRC confirmed that the site contained concentrations of radium-226, uranium-235, and uranium-238 above background levels for the area. The investigation revealed that the likely source of the contamination was $M \& C$ Nuclear, Inc., of Attleboro, Massachusetts. Apparently, the facility had disposed of trash and other materials at the Shpack site, including zirconium ashes associated with nuclear fuel operations that were conducted from 1957 to 1965 (Bechtel National, Inc. 1984). In agreement with the NRC and other federal agencies, responsibility for remedial action was subsequently assumed by DOE.

In 1980, a radiological survey was conducted by ORNL to characterize the extent of contamination at the site. The distribution of the contamination was found to be uneven and spotty, both horizontally and vertically, and in many cases, contamination extended into the groundwater (Cottrell et al. 1981). The ORNL survey confirmed NRC results, which indicated that the main radioactive contaminants are radium-226, uranium-234, uranium-235, and uranium-238. On the basis of field observations and laboratory analyses, the uranium and radium do not appear to have a common source. The radium is thought to have originated from the manufacture of electronic switches for military applications (Bechtel National, Inc. 1982). Depleted, normal, and enriched uranium were found in contaminated suil and metal objects. Uranium isotope concentration ratios (uranium-238:uranium-234:uranium-235) found in Shpack site soils range from 1:120:7.7 for enriched uranium to 1:0.17:0.016 for depleted uranium (Bechtel National, Inc. 1984). After the ORNL survey, DOE designated the Shpack site as a candidate for remediation under FUSRAP. In 1981, the site was fenced to restrict access.

Another radiological survey was conducted by Bechtel National, Inc., and Eberline Instrument Corporation in 1982 to evaluate possible remedial action alternatives. No contamination from radiological materials beyond the boundary of the site and no elevated concentrations of radionuclides in off-site groundwater were found. In this study, it was concluded that additional characterization work would be necessary to better define subsurface contamination before remedial actions could be implemented. This characterization has not yet been completed. Currently, the site is on the U.S. Environmental Protection Agency's National Priorities List, the site is closed, and the area is undeveloped.

\subsection{DERIVATION OF CLEANUP GUIDELINES}

Although most DOE cleanup guidelines applicable to remedial actions at FUSRAP sites are generic in nature (DOE 1990), uranium guidelines are derived on a site-specific basis. The purpose of this report is to present the derivation of the residual radioactive material guidelines 
for uranium (i.e., uranium-234, uranium-235, and uranium-238) that are applicable to remedial action at the Shpack site; that is, the residual concentration of uranium in a homogeneously contaminated area that must not be exceeded if the site is to be released for use without radiological restrictions. On the assumption that uranium is the only radionuclide present at an above-background concentration, the derivation of site-specific uranium guidelines for the Shpack site was based on a dose limit of $100 \mathrm{mrem} / \mathrm{yr}$ (DOE 1990). The RESRAD computer code, which implements the methodology described in the DOE manual for implementing residual radioactive material guidelines (Gilbert et al. 1989), was used to derive these guidelines. The DOE will establish the final uranium guidelines for the Shpack site by applying the as low as reasonably achievable (ALARA) policy to the derived guidelines presented in this report. 


\section{SCENARIO DEFINITIONS}

Three potential exposure scenarios were considered for the Shpack site. In all scenarios it is assumed that, at some time within 1000 years, the site will be released for use without radiological restrictions following decontamination.

Scenario A (the expected scenario) assumes recreational use of the site. It is assumed that, at some time in the future, the site will be used as a public park. A hypothetical person spends 15 hours per week, 50 weeks per year in the decontaminated area of the park. The recreationist does not ingest drinking water, plant foods, or fish from the decontaminated area, or ingest meat or milk from livestock raised in the decontaminated area.

Scenario B (a plausible scenario) assumes industrial use of the site. A hypothetical person is assumed to work in the area of the site for 8 hours per day (6 hours outdoors and 2 hours indoors), 5 days per week, 50 weeks per year. The industrial worker does not ingest drinking water, plant foods, or fish from the decontaminated area, or ingest meat or milk from livestock raised in the decontaminated area.

Scenario C (a possible but unlikely scenario) assumes a resident farmer in the immediate vicinity of the siie who drinks water obtained from a well located at the downgradient edge of the decontaminated area, ingests plant foods grown in a garden in the decontaminated area, and ingests meat and milk from livestock raised in the decontaminated area. All water used by the farmer is drawn from the well. The individual also ingests fish taken from a pond adjacent to and downstream of the decontaminated area.

Potential radiation doses resulting from eight exposure pathways were analyzed: (1) direct exposure to external radiation from the decontaminated soil material, (2) internal radiation from inhalation of contaminated dust, (3) internal radiation from inhalation of emanating radon-222, (4) internal radiation from ingestion of plant foods grown in the decontaminated area and irrigated with water drawn from a well located at the downgradient edge of the decontaminated area, (5) internal radiation from ingestion of meat from livestock fed with fodder grown in the decontaminated area and water drawn from the well, (6) internal radiation from ingestion of milk from livestock fed with fodder grown in the decontaminated area and water drawn from the well, (7) internal radiation from ingestion of aquatic food (fish) from a pond, and (8) internal radiation from drinking water drawn from the well.

The RESRAD computer code (Gilbert et al. 1989) was used to calculate the potential radiation doses to the hypothetical future recreationist, industrial worker, or resident farmer on the basis of the following assumptions:

- The resident farmer spends $50 \%$ of his or her time indoors in the decontaminated area, $25 \%$ outdoors in the decontaminated area, and $25 \%$ away from the decontaminated area. The industrial worker spends 2000 hours per year on-site ( $25 \%$ indoors and $75 \%$ outdoors). The recreationist spends 750 hours per year on-site, all outdoors.

- The walls, floor, and foundation of the house or office building reduce external exposure by $30 \%$; the indoor dust level is $40 \%$ of the outdoor dust level (Gilbert et al. 1989). 


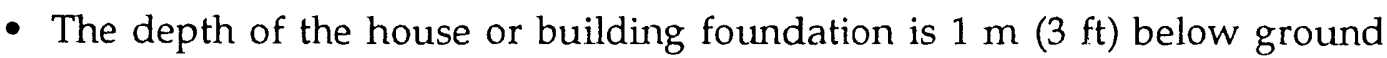
surface, with an effective radon diffusion coefficient of $2 \times 10^{-8} \mathrm{~m}^{2} / \mathrm{s}$.

- The size of the decontaminated area is large enough that $50 \%$ of the plant food diet consumed by the resident farmer is grown in a garden in the decontaminated area. The industrial worker or recreationist does not consume these plant foods.

- The size of the decontaminated area is large enough to provide sufficient meat and milk for the resident farmer from livestock raised (i.e., foraged) in the decontaminated area. The industrial worker or recreationist does not consume this meat or milk.

- Vegetables are irrigated by and livestock are provided with water drawn from the well located adjacent to the decontaminated area.

- The adjacent pond provides $50 \%$ of the aquatic food consumed by the resident farmer. The industrial worker or recreationist does not consume any aquatic food from the decontaminated area.

- The adjacent well provides $100 \%$ of the drinking water consumed by the resident farmer. The industrial worker or recreationist does not consume this drinking water.

- After remedial action, no cover material is placed over the decontaminated area.

- Soil and groundwater concentration data obtained in the 1981 ORNL survey report (Cottrell et al. 1981) are used to estimate the distribution coefficients for uranium and radium. The distribution coefficients for thorium are estimated on the basis of soil properties (Redmon 1991). The distribution coefficients used in the RESRAD analysis are 16,13 , and $7500 \mathrm{~cm}^{3} / \mathrm{g}$ for uranium, radium, and thorium, respectively.

- The thickness of the contaminated zone and the depth to the groundwater table are conservative average values from ORNL measurements (Cottrell et al. 1981). Only the results from boreholes with heavy contamination were considered. The values determined were both $0.76 \mathrm{~m}(2 \mathrm{ft})$.

- The erosion rate of the contaminated zone is set at $0 \mathrm{~m} / \mathrm{yr}$ because of the swampy characteristic of the landfill. Because of lack of information, the water table drop rate is also set at $0 \mathrm{~m} / \mathrm{yr}$. Comparative analysis of results from these parametric values and results from default values $(0.001 \mathrm{~m} / \mathrm{yr})$ does not show any noticeable differences.

All pathways considered for Scenarios A, B, and C are summarized in Table 1. 
TABLE 1 Summary of Pathways for Scenarios A, B, and C at the Shpack Site

\begin{tabular}{|c|c|c|c|}
\hline Pathway & Scenario A & Scenario B & Scenario $\mathrm{C}$ \\
\hline External exposure & Yes & Yes & Yes \\
\hline Inthalation & Yes & Yes & Yes \\
\hline Radon & Yes & Yes & Yes \\
\hline Ingestion of plant foods & No & $\mathrm{Nc}$ & Yes \\
\hline Ingestion of meat & No & No & Yes \\
\hline Ingestion of milk & No & No & Yes \\
\hline Ingestion of fish & No & No & Yes \\
\hline Ingestion of water ${ }^{b}$ & No & No & Yes \\
\hline
\end{tabular}

aScenario A, recreationist; Scenario B, industrial worker; Scenario C, resident farmer.

bSource of water used: $100 \%$ well water for drinking, irrigation, and livestock for Scenario C. 


\section{DOSE/SOURCE CONCENTRATION RATIOS}

The RESRAD computer code (Gilbert et al. 1989) was used to calculate the dose/source concentration ratio $\operatorname{DSR}_{\mathrm{ip}}(\mathrm{t})$ for uranium isotope $\mathrm{i}$ and pathway $\mathrm{p}$ at time $t$ after decontamination. The time frame considered in this analysis was 1000 years. Radioactive decay and ingrowth were considered in deriving the dose/source concentration ratios. The various parameters used in the RESRAD code for this analysis are listed in the Appendix. The calculated maximum dose/source concentration ratios for all pathways are presented in Tables 2 through 4 for Scenarios A, B, and C, respectively. For Scenarios A and B, the maximum dose/source concentration ratios would occur at time zero (immediately after decontamination). For Scenario $C$, the maximum dose/source concentration ratio for uranium isotopes would occur at time 507 years following decontamination. The primary patı ay for Scenarios A and B would be inhalation; for Scenario $C$, the primary pathway would be i: igestion of drinking water from the well.

The summation of $\operatorname{DSR}_{i p}(t)$ for all pathways $p$ is the $\operatorname{DSR}_{i}(t)$ for the $i^{\text {th }}$ isotope, that is,

$$
D S R_{i}(t)=\sum_{p} D S R_{i p}(t)
$$

The total dose/source concentration ratio for total uranium (enriched, depleted, or normal) can be calculated as

$$
D S R(t)=\sum_{i} W_{i} D S R_{i}(t)
$$

where $W_{i}$ is the existing activity concentration fraction at the site for uranium-234, uranium-235, and uranium-238. The activity concentration ratio for uranium-234, uranium-235, and uranium-238 varies from place to place at the Shpack site. When the concentration ratio for enriched uranium in Section $1.2(1: 120: 7.7)$ was used, the $W_{i}$ was $1 / 128.7,120 / 128.7$, and $7.7 / 128.7$ for uranium-238, uranium-234, and uranium-2.35, respectively; the $W_{i}$ was $1 / 1.186$, $0.17 / 1.186$, and $0.016 / 1.186$ for uranium-238, uranium-234, and uranium-235, respectively, when the concentration ratio for depleted uranium in Section 1.2 (1:0.17:0.016) was used. For normal (natural) uranium, the $W_{i}$ was $1 / 2.046,1 / 2.046$, and $0.046 / 2.046$ for uranium-238, uranium-234, and uranium-235, respectively. The total dose/source concentration ratios derived for single nuclides are provided in Table 5. Table 6 gives example total dose/source concentration ratios derived for enriched, depleted, and normal uranium on the basis of the $W_{i}$ values given above. As can be seen, the total dose/source concentration ratio for total uranium does not vary much for enriched, depleted, and normal uranium because (1) uranium-234 and uranium-238 have similar total dose/source concentration ratios and (2) the uranium-235 concentration is small compared to the concentration of uranium-238 (for depleted uranium) or uranium-234 (for enriched uranium). Therefore, the dose contribution from uranium-235 is small compared to the combined dose contribution from uranium-234 and uranium-238 (it is about $2 \%$ to $5 \%$ for depleted uranium and about $10 \%$ to $30 \%$ for enriched uranium, depending on the exposure scenario considered). Total dose/source concentration ratios were used to determine the allowable residual radioactivity for uranium at the Shpack site. 
TABLE 2 Maximum Dose/Sciurce Concentration Ratios for Scenario A at the Shpack Site

\begin{tabular}{lccc}
\hline & \multicolumn{3}{c}{$\begin{array}{c}\text { Maximum Dose/Source Concentration Ratio } \\
(\mathrm{mrem} / \mathrm{yr}) /(\mathrm{pCi} / \mathrm{g})^{\mathrm{a}}\end{array}$} \\
\cline { 2 - 4 } \multicolumn{1}{c}{ Pathway } & Uranium-234 & Uranium-235 & Uranium-238 \\
\hline External exposure & $1.1 \times 10^{-4}$ & $7.5 \times 10^{-2}$ & $1.1 \times 10^{-2}$ \\
Inhalation & $1.8 \times 10^{-2}$ & $1.7 \times 10^{-2}$ & $1.7 \times 10^{-2}$ \\
Radon & 0 & 0 & 0 \\
Ingestion of plant foods & 0 & 0 & 0 \\
Ingestion of meat & 0 & 0 & 0 \\
Ingestion of milk & 0 & 0 & 0 \\
Ingestion of fish & 0 & 0 & 0 \\
Ingestion of water & 0 & 0 & 0 \\
\hline
\end{tabular}

${ }^{a}$ Maximum dose/source concentration ratios would occur at time zero (immediately following decontamination); all values are reported to two significant figures.

TABLE 3 Maximum Dose/Source Concentration Ratios for Scenario B at the Shpack Site

\begin{tabular}{lccc}
\hline & \multicolumn{3}{c}{\begin{tabular}{c} 
"'aximum \\
Pathway \\
\cline { 2 - 4 } \multicolumn{1}{c}{ Patsem/yr) $/(\mathrm{pCi} / \mathrm{g})^{\mathrm{a}}$}
\end{tabular}} \\
\cline { 2 - 4 } & Uranium-234 & Uranium-235 & Uranium-238 \\
\hline External exposure & $2.6 \times 10^{-4}$ & $1.8 \times 10^{-1}$ & $2.6 \times 10^{-2}$ \\
Inhalation & $4.1 \times 10^{-2}$ & $3.8 \times 10^{-2}$ & $3.8 \times 10^{-2}$ \\
Radon & 0 & 0 & 0 \\
Ingestion of plant foods & 0 & 0 & 0 \\
Ingestion of meat & 0 & 0 & 0 \\
Ingestion of milk & 0 & 0 & 0 \\
Ingestion of fish & 0 & 0 & 0 \\
Ingestion of water & 0 & 0 & 0 \\
\hline
\end{tabular}

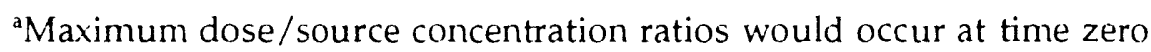
(immediately following decontamination); all values are reported to two significant figures. 
TABLE 4 Maximum Dose/Source Concentration Ratios for Scenario C at the Shpack Site

\begin{tabular}{lccc}
\hline & \multicolumn{3}{c}{$\begin{array}{c}\text { Maximum } \\
\text { Pose/Source Concentration Ratio } \\
\text { Pathway }\end{array}$} \\
\cline { 2 - 4 } & Uranium-234 & Uranium-235 & Uranium-238 \\
\hline External exposure & $1.7 \times 10^{-4}$ & $1.1 \times 10^{-3}$ & $1.0 \times 10^{-4}$ \\
Inhalation & $2.9 \times 10^{-4}$ & $1.6 \times 10^{-3}$ & $1.2 \times 10^{-4}$ \\
Radon & $2.8 \times 10^{-5}$ & 0 & $5.9 \times 10^{-9}$ \\
Ingestion of plant foods & $1.3 \times 10^{-1}$ & $2.0 \times 10^{-1}$ & $1.2 \times 10^{-1}$ \\
Ingestion of meat & $1.4 \times 10^{-1}$ & $2.2 \times 10^{-1}$ & $1.3 \times 10^{-1}$ \\
Ingestion of milk & $3.6 \times 10^{-2}$ & $3.5 \times 10^{-2}$ & $3.5 \times 10^{-2}$ \\
Ingestion of fish & $2.6 \times 10^{-3}$ & $2.2 \times 10^{-2}$ & $2.5 \times 10^{-3}$ \\
Ingestion of water & 1.0 & 1.6 & $9.6 \times 10^{-1}$ \\
\hline
\end{tabular}

a Maximum dose/source concentration ratios would occur at time 507 years following decontamination; all values are reported to two significant figures.

TABLE 5 Total Dose/Source Concentration Ratios for Uranium at the Shpack Site

\begin{tabular}{lccc}
\hline & \multicolumn{2}{c}{$\begin{array}{c}\text { Total Dose/Source Concentration Ratio } \\
(\mathrm{mrem} / \mathrm{yr}) /(\mathrm{pCi} / \mathrm{g})^{\mathrm{a}}\end{array}$} \\
\cline { 2 - 4 } Radionuclide & Scenario A & Scenario B & Scenario C \\
\hline Uranium-234 & $1.9 \times 10^{-2}$ & $4.1 \times 10^{-2}$ & 1.3 \\
Uranium-235 & $9.2 \times 10^{-2}$ & $2.2 \times 10^{-1}$ & 2.0 \\
Uranium-238 & $2.8 \times 10^{-2}$ & $6.4 \times 10^{-2}$ & 1.3 \\
\hline
\end{tabular}

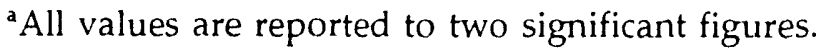


TABLE 6 Example Total Dose/Source Concentration Ratios for Total Uranium at the Shpack Site

\begin{tabular}{lccc}
\hline & \multicolumn{2}{c}{$\begin{array}{c}\text { Total Dose/Source Concentration Ratio } \\
(\mathrm{mrem} / \mathrm{yr}) / \mathrm{pCi} / \mathrm{g})^{\mathrm{a}}\end{array}$} \\
\cline { 2 - 4 } Total Uranium $^{\mathrm{b}}$ & Scenario A & Scenario B & Scenario C \\
\hline Enriched & $2.3 \times 10^{-2}$ & $5.2 \times 10^{-2}$ & 1.4 \\
Depleted & $2.7 \times 10^{-2}$ & $6.3 \times 10^{-2}$ & 1.3 \\
Normal & $2.5 \times 10^{-2}$ & $5.6 \times 10^{-2}$ & 1.3 \\
\hline
\end{tabular}

${ }^{a}$ All values are reported to two significant figures.

'The concentıaiicn ratios (uranium-238: uranium-234: uranium-235) are 1:120:7.7 for enriched uranium, 1:0.17:0.016 for depleted uranium, and 1:1:0.046 for natural uranium. 


\section{RESIDUAL RADIOACTIVE MATERIAL GUIDELINES}

The residual radioactive material guideline is the concentration of residual radioactive material that can remain in a decontaminated area and still allow use of the area without radiological restrictions. Given the DOE annual radiation dose limit of $100 \mathrm{mrem} / \mathrm{yr}$ for an individual (DOE 1990), the residual radioactive material guideline $G$ for uranium at the Shpack site can be calculated as

$$
G=100 / D S R
$$

where DSR is the total dose/source concentration ratio given in Tables 5 and 6 . The calculated residual radioactive material guidelines for individual radionuclides (uranium-234, uranium-235, and uranium-238) are presented in Table 7. Table 8 gives the example total uranium (enriched, depleted, and normal) radioactive material guidelines derived for the Shpack site on the basis of the total dose/source concentration ratios provided in Table 6.

The individual radionuclide guidelines listed in Table 7 can be applied to the entire site if concentrations of uranium isotopes (uranium-234, uranium-235, and uranium-238) are measured. The law of sum of fractions can be used to check whether uranium isotopes are within dose and cleanup limits. To use the individual radionuclide guidelines, the uranium concentrations for uranium-234, uranium-235, and uranium-238 must be measured. Because uranium isotope concentration ratios vary from place to place at the Shpack site, the total uranium guidelines listed in Table 8 cannot be applied to the entire site. The following process was used to obtain a practical uranium guideline for the Shpack site. Table 5 shows that uranium-234 and uranium-238 have similar total dose/source concentration ratios for all scenarios. From the analysis in Section 3, it is known that the uranium-235 dose contribution for the Shpack site is about $2 \%$ to $30 \%$ of the combined dose from uranium- 234 and uranium238. Therefore, if the combined concentration of uranium- 234 and uranium-238 is less than $70 \%$ of the smaller guideline given for uranium-234 or uranium-238 in Table 7, the total dose from uranium isotopes (including uranium-234, uranium-235, and uranium-238) will be less than the dose limit of $100 \mathrm{mrem} / \mathrm{yr}$. Hence, the combined uranium-238 and uranium-234 guideline is $2500 \mathrm{pCi} / \mathrm{g}$ for Scenario A, $1100 \mathrm{pCi} / \mathrm{g}$ for Scenario B, and $53 \mathrm{pCi} / \mathrm{g}$ for Scenario C. There are cther possible methods of setting practical guidelines for the site, and these methods may be used by DOE in establishing the guidelines.

TABLE 7 Residual Radioactive Material Guidelines for the Shpack Site

\begin{tabular}{lccc}
\hline & \multicolumn{3}{c}{ Guideline $(\mathrm{pCi} / \mathrm{g})^{\mathrm{a}}$} \\
\cline { 2 - 4 } Radionuclide & Scenario A & Scenario B & Scenario C \\
\hline Uranium-234 & 5400 & 2400 & 76 \\
Uranium-235 & 1100 & 450 & 49 \\
Uranium-238 & 3600 & 1600 & 80 \\
\hline
\end{tabular}

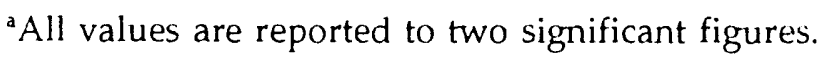


TABLE 8 Example Total Uranium Residual Radioactive Material Guidelines for the Shpack Site

\begin{tabular}{lccc}
\hline & \multicolumn{3}{c}{${\text { Guideline }(\mathrm{pCi} / \mathrm{g})^{\mathrm{a}}}$} \\
\cline { 2 - 4 } Total Uranium $^{\mathrm{b}}$ & Scenario A & Scenario B & Scenario C \\
\hline Enriched & 4300 & 1900 & 74 \\
Depleted & 3700 & 1600 & 78 \\
Normal & 4000 & 1800 & 77 \\
\hline
\end{tabular}

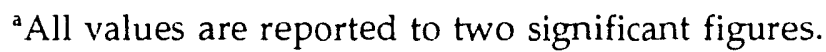

${ }^{b}$ The concentration ratios (uranium-238: uranium-234: uranium-235) are 1:120:7.7 for enriched uranium, 1:0.17:0.016 for depleted uranium, and 1:1:0.046 for natural uranium.

When implementing the derived radionuclide guidelines for decontamination of a site, the law of sum of fractions applies. That is, the summation of the fractions of concentrations of radionuclide $i\left(S_{i}\right.$ divided by its guideline $G_{i}$ and averaged over an area of $100 \mathrm{~m}^{2}$ [120 yd] and a depth of $15 \mathrm{~cm}$ [6 in.]) should not be greater than unity:

$$
\sum_{i} S_{i} / G_{i} \leq 1
$$

The derived guidelines are for a large, homogeneously contaminated area. For an isolated, small area of contamination, the allowable concentration that can remain on-site may be higher than the homogeneous guideline, depending on the size of the area of contamination. 


\section{REFERENCES}

Bechtel National, Inc., 1982, Radiological Characterization of the Shpack Landfill, Norton, MA, Survey Plan, April.

Bechtel National, Inc., 1984, Radiological Survey of the Former Shpack Landfill, DOE/OR/20722-4 (DE84012082), prepared for U.S. Department of Energy, May.

Cottrell, W.D., et al., 1981, Radiological Survey of the Shpack Landfill, Norton, Massachusetts, DOE/EV-0005/31, ORNL 5799, prepared by Oak Ridge National Laboratory for U.S. Department of Energy, Dec.

Geo-Centers, Inc., 1980, Technical Report Results of Ground Penetrating Radar Survey at Norton/Attleboro, Massachusetts, GC-TR-80-1085, prepared for Oak Ridge National Laboratory, Oct.

Gilbert, T.L., et al., 1989, A Manual for Implementing Residual Radioactive Material Guidelines, ANL/ES-160, DOE/CH/8901, prepared by Argonne National Laboratory for U.S. Department of Energy, June.

Peterson, J., 1981, letter from J. Peterson (Argonne National Laboratory, Argonne, Ill.) to D.W. Connor (Argonne National Laboratory, Argonne, Ill.), May 21.

Redmon, M., 1991, personal communication from M. Redmon (Bechtel National, Inc., Oak Ridge, Tenn.) to C. Yu (Argonne National Laboratory, Argonne, Ill.), May 6.

U.S. Department of Energy, 1990, Radiation Protection of the Public and the Environment, DOE Order 5400.5, Feb. 8. 


\section{APPENDIX:}

\section{PARAMETERS USED IN THE ANALYSIS OF THE SHPACK SITE}

The parametric values used in the RESRAD code for the analysis of the Shpack Site are listed in Table A.1. All parametric values are reported to three significant figures. Some parametric values are specific to the Shpack Site, others are generic.

TABLE A.1 Parameters Used in the RESRAD Code for the Analysis of the Shpack Site

\begin{tabular}{|c|c|c|c|c|}
\hline \multirow[b]{2}{*}{ Parameter } & \multicolumn{4}{|c|}{ Value } \\
\hline & Unit & Scenario A & Scenario B & Scenario C \\
\hline Area of contaminated zone $e^{a}$ & $\mathrm{~m}^{2}$ & 32,400 & 32,400 & 32,400 \\
\hline Thickness of contaminated zone ${ }^{a}$ & $\mathrm{~m}$ & 0.76 & 0.76 & 0.76 \\
\hline Length parallel to aquifer flow ${ }^{\mathrm{a}}$ & $\mathrm{m}$ & 200 & 200 & 200 \\
\hline Cover depth & $\mathrm{m}$ & 0 & 0 & 0 \\
\hline Density of contaminated zone $e^{b}$ & $\mathrm{~g} / \mathrm{cm}^{3}$ & 1.85 & 1.85 & 1.85 \\
\hline Contaminated zone erosion rate ${ }^{a}$ & $\mathrm{~m} / \mathrm{yr}$ & 0 & 0 & 0 \\
\hline Contaminated zone total porosity & $-c$ & 0.4 & 0.4 & 0.4 \\
\hline Contaminated zone effective porosity & $-c$ & 0.2 & 0.2 & 0.2 \\
\hline Contaminated zone hydraulic conductivity & $\mathrm{m} / \mathrm{yr}$ & 100 & 100 & 100 \\
\hline Contaminated zone b parameter & $-^{c}$ & 5.3 & 5.3 & 5.3 \\
\hline Evapotranspiration coefficient & $-c$ & 0.6 & 0.6 & 0.6 \\
\hline Precipitation $^{\mathrm{d}}$ & $\mathrm{m} / \mathrm{yr}$ & 1.06 & 1.06 & 1.06 \\
\hline Irrigation & $\mathrm{m} / \mathrm{yr}$ & 0.2 & 0.2 & 0.2 \\
\hline Irrigation mode & $-c$ & not used & not used & overhead \\
\hline Runoff coefficient ${ }^{d}$ & $-c$ & 0.5 & 0.5 & 0.5 \\
\hline Watershed area for nearby pond & $\mathrm{m}^{2}$ & not used & not used & $1,000,000$ \\
\hline Density of saturated zone $e^{b}$ & $\mathrm{~g} / \mathrm{cm}^{3}$ & 1.85 & 1.85 & 1.85 \\
\hline Saturated zone total porosity & $-c$ & not used & not used & 0.4 \\
\hline Saturated zone effective porosity & 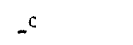 & not used & not used & 0.2 \\
\hline Saturated zone hydraulic conductivity ${ }^{b}$ & $\mathrm{~m} / \mathrm{yr}$ & not used & not used & 4,450 \\
\hline Saturated zone hydraulic gradient ${ }^{b}$ & $-c$ & not used & not used & 0.001 \\
\hline Saturated zone b parameter & $-c$ & 5.3 & 5.3 & 5.3 \\
\hline Water table drop rate ${ }^{\mathrm{a}}$ & $\mathrm{m} / \mathrm{yr}$ & not i!sed & not used & 0 \\
\hline $\begin{array}{l}\text { Well pump intake depth } \\
\text { (below water table) }\end{array}$ & $\mathrm{m}$ & not used & not used & 10 \\
\hline $\begin{array}{l}\text { Model: nondispersion ND) or } \\
\text { mass-balance }(\mathrm{MB})\end{array}$ & $-c$ & not used & not used & ND \\
\hline Number of unsaturated zone strata ${ }^{a}$ & $-c$ & not used & not used & 0 \\
\hline Distribution coefficient & $\mathrm{cm}^{3} / \mathrm{g}$ & & & \\
\hline \multicolumn{5}{|l|}{ Contaminated zone } \\
\hline Uranium-234 ${ }^{\mathrm{e}}$ & & 16 & 16 & 16 \\
\hline Uranium-235 & & 16 & 16 & 16 \\
\hline Uranium-238 & & 16 & 16 & 16 \\
\hline Actinium-227 & & 20 & 20 & 20 \\
\hline
\end{tabular}




\begin{tabular}{|c|c|c|c|c|}
\hline \multirow[b]{2}{*}{ Parameter } & \multicolumn{4}{|c|}{ Value } \\
\hline & Unit & Scenario A & Scenario B & Scenario C \\
\hline Protactinium-231 & & 50 & 50 & 50 \\
\hline Lead $-210^{f}$ & & 100 & 100 & 100 \\
\hline Radium-226, & & 13 & 13 & 13 \\
\hline Thorium-230 & & 7,500 & 7,500 & 7,500 \\
\hline \multicolumn{5}{|l|}{ Saturated zone } \\
\hline Uranium-234 & & 16 & 16 & 16 \\
\hline Uranium-235 & & 16 & 16 & 16 \\
\hline Uranium-238 & & 16 & 16 & 16 \\
\hline Actinium-227 & & 20 & 20 & 20 \\
\hline Protactinium-231 & & 50 & 50 & 50 \\
\hline Lead $-210^{f}$ & & 100 & 100 & 100 \\
\hline Radium-226, & & 13 & 13 & 13 \\
\hline Thorium-230 & & 7,500 & 7,500 & 7,500 \\
\hline Inhalation rate & $\mathrm{m}^{3} / \mathrm{yr}$ & 8,400 & 8,400 & 8,400 \\
\hline Mass loading for inhalation & $\mathrm{g} / \mathrm{m}^{3}$ & 0.0002 & 0.0002 & 0.0002 \\
\hline $\begin{array}{l}\text { Occupancy and shielding factor, } \\
\text { external gamma }\end{array}$ & $-c$ & 0.086 & 0.21 & 0.6 \\
\hline Occupancy factor, inhalation ${ }^{\mathrm{a}}$ & $-c$ & 0.086 & 0.19 & 0.45 \\
\hline Shape factor, external gamma & $-c$ & 1 & 1 & 1 \\
\hline $\begin{array}{l}\text { Dilution length for airborne dust, } \\
\text { inhalation }\end{array}$ & $\mathrm{m}$ & 3 & 3 & 3 \\
\hline Fruit, vegetable, and grain consumption & $\mathrm{kg} / \mathrm{yr}$ & not used & not used & 160 \\
\hline Leafy vegetable consumption & $\mathrm{kg} / \mathrm{yr}$ & not used & not used & 14 \\
\hline Milk consumption & $L / y r$ & not used & not used & 92 \\
\hline Meat and poultry consumption & $\mathrm{kg} / \mathrm{yr}$ & not used & not used & 63 \\
\hline Fish consumption & $\mathrm{kg} / \mathrm{yr}$ & not used & not used & 5.4 \\
\hline Other seafood consumption & $\mathrm{kg} / \mathrm{yr}$ & not used & not used & 0.9 \\
\hline Drinking water intake & $\mathrm{L} / \mathrm{yr}$ & not used & not used & 410 \\
\hline Fraction of drinking water from site ${ }^{a}$ & $-c$ & not used & not used & 1 \\
\hline Fraction of aquatic food from site ${ }^{\mathrm{a}}$ & $--^{c}$ & not used & not used & 0.5 \\
\hline Livestock fodder intake for meat & $\mathrm{kg} / \mathrm{d}$ & not used & not used & 68 \\
\hline Livestock fodder intake for milk & $\mathrm{kg} / \mathrm{d}$ & not used & not used & 55 \\
\hline Livestock water intake for meat & $\mathrm{L} / \mathrm{d}$ & not used & not used & 50 \\
\hline Livestock water intake for milk & $\mathrm{L} / \mathrm{d}$ & not used & not used & 160 \\
\hline Mass loading for foliar deposition & $\mathrm{g} / \mathrm{m}^{3}$ & not used & not used & 0.0001 \\
\hline Depth of soil mixing layer & $\mathrm{m}$ & 0.15 & 0.15 & 0.15 \\
\hline Depth of roots & $\mathrm{m}$ & not used & not used & 0.9 \\
\hline $\begin{array}{l}\text { Groundwater fractional usage } \\
\text { (balance from surface water) }^{\mathrm{a}}\end{array}$ & $-c$ & & & \\
\hline Drinking water & & not used & not used & 1 \\
\hline Livestock water & & not used & not used & 1 \\
\hline Irrigation & & not used & not used & 1 \\
\hline Total porosity of the cover material & $-c$ & 0.4 & 0.4 & 0.4 \\
\hline $\begin{array}{l}\text { Total porosity of the house or building } \\
\text { foundation }\end{array}$ & $-c$ & 0.1 & 0.1 & 0.1 \\
\hline
\end{tabular}




\begin{tabular}{|c|c|c|c|c|}
\hline \multirow[b]{2}{*}{ Parameter } & \multicolumn{4}{|c|}{ Value } \\
\hline & Unit & Scenario A & Scenario B & Scenario $C$ \\
\hline $\begin{array}{l}\text { Volumetric water content of the cover } \\
\text { material }\end{array}$ & $--^{c}$ & 0.05 & 0.05 & 0.05 \\
\hline Volumetric water content of the foundation & $-c$ & 0.01 & 0.01 & 0.01 \\
\hline Diffusion coefficient for radon gas & $\mathrm{m}^{2} / \mathrm{s}$ & & & \\
\hline in cover material & & $2.0 \times 10^{-6}$ & $2.0 \times 10^{-6}$ & $2.0 \times 10^{-6}$ \\
\hline in foundation material & & $2.0 \times 10^{-8}$ & $2.0 \times 10^{-8}$ & $2.0 \times 10^{-8}$ \\
\hline in contaminated zone soil & & $2.0 \times 10^{-6}$ & $2.0 \times 10^{-6}$ & $2.0 \times 10^{-6}$ \\
\hline Emanating power of radon gas & $-c$ & 0.2 & 0.2 & 0.2 \\
\hline Radon vertical dimension of mixing & $\mathrm{m}$ & 2.0 & 2.0 & 2.0 \\
\hline Average annual wind speed & $\mathrm{m} / \mathrm{s}$ & 2.0 & 2.0 & 2.0 \\
\hline Average building air exchange rate & $1 / \mathrm{h}$ & 1.0 & 1.0 & 1.0 \\
\hline Height of the building (room) & $\mathrm{m}$ & 2.5 & 2.5 & 2.5 \\
\hline $\begin{array}{l}\text { Bulk density of house or building } \\
\text { foundation }\end{array}$ & $\mathrm{g} / \mathrm{cm}^{3}$ & 2.4 & 2.4 & 2.4 \\
\hline Thickness of house or building foundation & $\mathrm{m}$ & 0.15 & 0.15 & 0.15 \\
\hline Building depth below ground surface & $\mathrm{m}$ & 1.0 & 1.0 & 1.0 \\
\hline Fraction of time spent indoors $\mathrm{a}^{\mathrm{a}}$ & $-^{c}$ & 0 & 0.057 & 0.5 \\
\hline Fraction of time spent outdoors ${ }^{a}$ & $-c$ & 0.086 & 0.171 & 0.25 \\
\hline
\end{tabular}

${ }^{a}$ Values based on site specifications or scenario assumptions.

${ }^{b}$ Values based on personal communication from M. Redmon (Bechtel National, Inc., Oak Ridge, Tenn.) to C. Yu (Argonne National Laboratory, Argonne, Ill.), May 6, 1991.

'Parameter is dimensionless.

${ }^{d}$ Values from Water and the Related Land Resources of the Coastal Region, Massachusetts, U.S. Department of Agriculture, 1978.

eValues derived from measured radionuclide concentrations of groundwater and soil samples by Oak Ridge National Laboratory, 1981.

'Radionuclide is a decay product. 

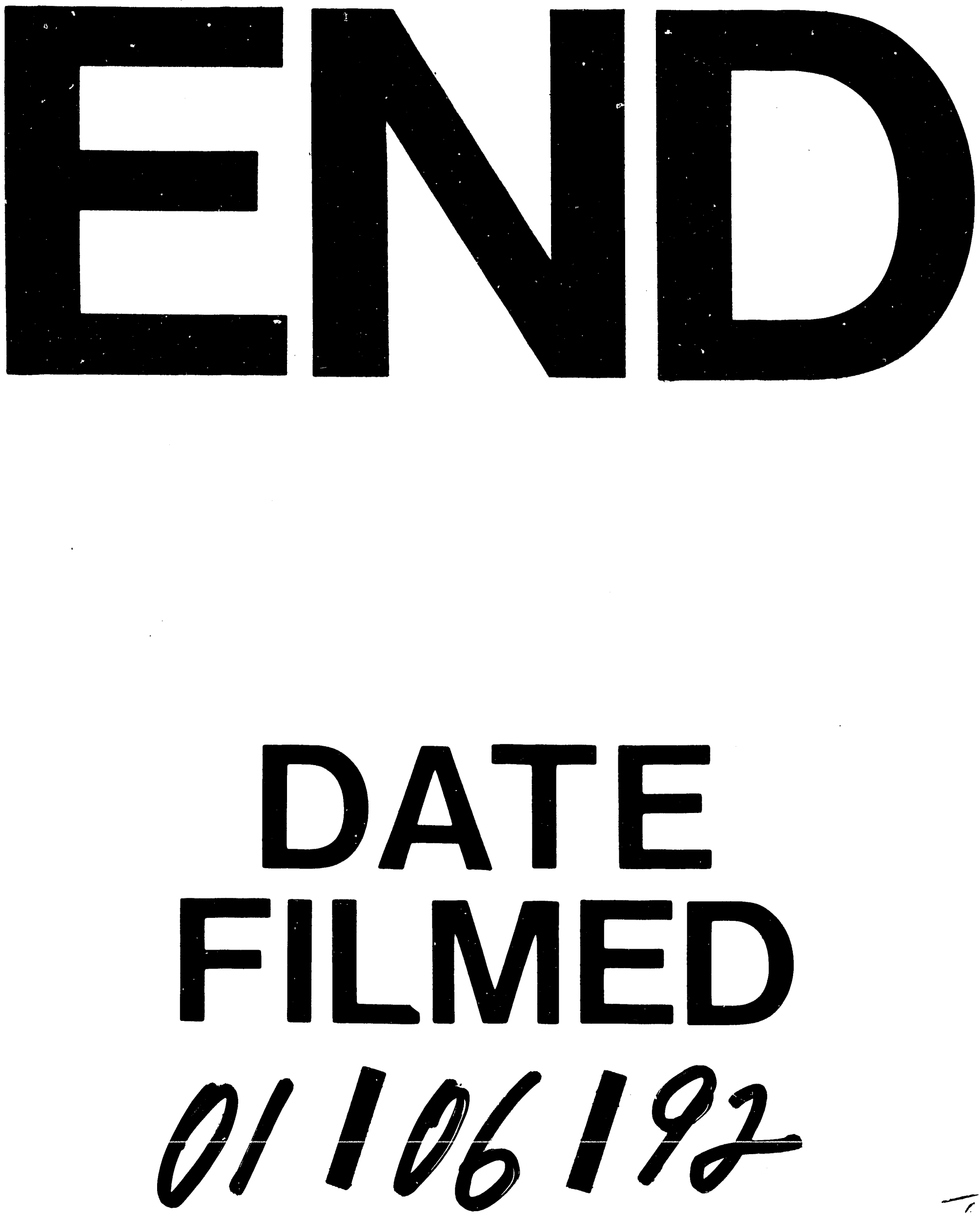

$T$ 
